JOSING: Journal of Nursing and Health

Volume 2, Nomor 2, Juni 2022

e-ISSN: 2745-7877

p-ISSN: 2746-0851

DOI: https://doi.org/10.31539/josing.v2i2.3439

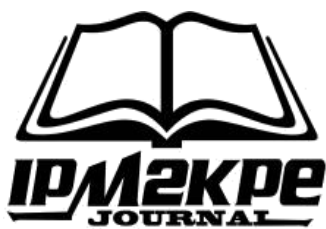

\title{
INFLUENCE OF HOSPITAL READINESS IN HANDLING COVID-19 ON COVID-19 INCIDENTS
}

\author{
Siti Solichah ${ }^{1}$, Rahmawati Husein $^{2}$, Elsye Maria Rosa ${ }^{3}$ \\ Yogyakarta Muhammadiyah University ${ }^{1,2,3}$ \\ lichah.sby@gmail.com ${ }^{1}$
}

\begin{abstract}
This study aims to determine the effect of hospital readiness in handling COVID-19 on the incidence of COVID-19 at Aisyiyah Siti Fatimah Hospital, Tulangan Sidoarjo, to optimize the ability to deal with the COVID-19 disaster. This type of research is a quantitative study with a cross-sectional analytic observational design. The results showed that most of the employees of Aisyiyah Fatimah Hospital in Tulangan Sidoarjo were aged between 21-30 years, namely 109 people (61.2\%). Based on gender, most of the respondents were women, namely 156 people (87.6\%). Based on education, most of the respondents have D3 education as many as 81 people (45.5\%). Meanwhile, based on years of service, most respondents worked for $1-5$ years as many as 87 people (48.9\%). Bivariate analysis showed that staff had a positive and significant effect on the number of suspected Covid-19 patients. In conclusion, the team is the more dominant factor or variable in influencing the handling of Covid-19 in the Covid-19 incident at Aisyiyah Siti Fatimah Hospital, Tulangan Sidoarjo.
\end{abstract}

Keywords: Covid-19 Incidence, Hospital Readiness, Handling Covid-19

\section{INTRODUCTION}

The start of 2020 has been a shocking year for everyone around the world, as the Corona Virus Pandemic (Covid-19) has caused panic everywhere. Hundreds of thousands if not millions of people have been infected, and thousands have died. Corona virus is a disease that infects the respiratory system in humans, causing respiratory and systemic symptoms. This is the first time this virus has attacked the people of Wuhan, China with a fairly high number of deaths. This case has symptoms of fever, fatigue and difficulty in breathing (Yuliana, 2020). According to data from the World Health Organization as many as 106 countries in the world have been exposed to the corona virus, with 2,804,796 confirmed cases and 193,710 deaths due to the corona virus (Pole et al., 2021; WHO, 2020).

Indonesia is also one of the countries reported to have been infected with Covid-19. Judging from the spread of Covid-19, which has reached all provinces in Indonesia, the number of cases and the number of deaths continues to grow, of which 1,686,373 positive cases have been confirmed, and 46,137 cases have died. This will affect Indonesian citizens' political, economic, social, cultural, defense, security, and welfare aspects. The Indonesian Government issued Presidential Decree No. 12 of 2020 concerning the Determination of Non-Natural Disasters Spreading Covid-19 as National Disasters (WHO, 2021).

With the number of cases increasing every day rapidly, there is a need for a response from health services to this pandemic, namely increasing the health system's capacity because the existing system has not accommodated requests with rapid spikes, only designed for average health service requests under normal conditions. The primary role of 
hospitals in emergencies and disasters is to be a provider of health services for affected communities. Therefore, hospitals must be resilient, in the sense of being able to withstand disturbances during emergency and disaster conditions to continue to provide health services. The surge capacity in the health system prioritizes space, Staff, Staff, and system (Utami et al., 2021).

The hospital is one of the facilities with a very significant position when a disaster occurs. Hospitals are also required to improve and ensure operational capabilities run as they should, even better, even in a disaster. Hospital readiness is the key to hospitals in facing a pandemic disaster. WHO has issued a preparedness guide for Covid-19 that hospitals can implement in optimizing service capabilities and preventing their health system from becoming overwhelmed, namely the Hospital readiness checklist for Covid-19, as a checking tool in supporting the readiness of hospitals to handle the surge in Covid-19 patients. With this screening tool, hospitals can prepare several vital components to respond to Covid-19 and have optimal preparedness for disasters (Abbasabadi et al., 2019).

The readiness of frontline health workers is also crucial, which relies on two main pillars, namely self-preparation and Hospital Readiness. Self-readiness depends on knowledge of Covid-19, a safe approach to patients, and adherence to self-protection measures. Hospital Readiness is reflected by preparing self-protection measures for all Staff at the hospital and providing clear protocols in handling Covid-19 patients. In addition, psychological health and the impact on officers during an outbreak must be targeted as a vital factor of preparedness (Suleiman et al., 2020).

Kaito et al., (2020) conducted a study at Keio University Hospital Japan, where the hospital preparedness by developing an incident management system and forming a multidisciplinary medical team that is specifically responsible for planning for Covid-19 prevention so that the handling of Covid-19 can be carried out independently optimal. This is the same thing that happened to Veterans Affairs Connecticut Healthcare in its readiness to deal with Covid-19 in line with Keio University Hospital Japan, namely the hospital implemented the formation of a multidisciplinary team with a centralized incident command body so that rapid policy making can help minimize the impact and optimize the ability to handle Covid-19 19 (Gupta \& Federman, 2020).

Aisyiyah Siti Fatimah Hospital is a type D hospital, which the Governor of East Java appointed as a Covid-19 referral hospital. Sidoarjo Aisyiyah Siti Fatimah Hospital is a type D hospital, which the Governor of East Java appointed as a Covid-19 referral hospital. As a type D referral hospital with limited facilities and resources, Aisyiyah Siti Fatimah Tulangan Sidoarjo Hospital seeks to prepare itself to have optimal capabilities in handling Covid-19 patients. When appointed, the hospital only had two isolation room beds without negative pressure, so they had to redesign the general inpatient room into 13 Covid-19 isolation beds. Hospitals also do not have a unique flow for Covid-19 patients because the existing facilities do not allow fast flow separation. The number of health workers they have is also limited because there is no specific plan to treat Covid-19 patients to maximize the existing health workers. In addition, the hospital has also formed a Covid-19 Task Force Team, which coordinates the handling of the Covid-19 disaster at Aisyiyah Siti Fatimah Hospital, Tulangan Sidoarjo. However, the implementation has not been optimal because the regulations that must be implemented often change suddenly, so coordination and communication are still lacking.

Based on the results of a survey conducted at Aisyiyah Siti Fatimah Hospital, Tulangan Sidoarjo, the number of visits by suspected and confirmed Covid-19 patients from early August 2020 to January 2021 increased to $45 \%$ in a day, tending to increase, but there 
was a gradual decline in February 2021 to May. 2021, and there was a 55\% jump again from June 2021 to July 2021. It can be seen that there are problems related to the readiness of the Aisyiyah Siti Fatimah Hospital in Sidoarjo in handling Covid-19 with Covid-19 cases, which tend to increase. So it is necessary to do further research on the effect of hospital readiness in handling Covid-19 on the Covid-19 incident at Aisyiyah Siti Fatimah Hospital Sidoarjo to realize the optimization of capabilities in handling Covid-19.

\section{RESEARCH METHOD}

The research was carried out at Aisyiyah Siti Fathimah Hospital, Tulangan Sidoarjo in October 2021. The research design used was quantitative analytic with a cross-sectional analytic observational design. The population in this study were both medical and nonmedical employees at Aisyiyah Siti Fatimah Hospital, Tulangan Sidoarjo. Determination of research sampling using a total sampling of employees, both medical and non-medical Aisyiyah Siti Fatimah Hospital, Sidoarjo, amounting to 178 people.

Data is collected through questionnaires and will be analyzed using univariate and multivariate analysis, and then statistical tests are carried out using validity tests, reliability tests, and multiple regressions.

\section{RESULTS}

\section{Characteristics of Respondents}

Table. 1

Characteristics of Respondents Based on Age, Gender, Education, and Length of Service

\begin{tabular}{|c|c|c|c|c|}
\hline No & Characteristics & Respondents & Numbers & Percentages (\%) \\
\hline \multirow[t]{5}{*}{1} & Age & $<21$ years & 3 & $1,7 \%$ \\
\hline & & $21-30$ years & 109 & $61,2 \%$ \\
\hline & & $31-40$ years & 44 & $24,7 \%$ \\
\hline & & $>40$ years & 22 & $12,4 \%$ \\
\hline & Total & & 178 & $100 \%$ \\
\hline \multirow[t]{3}{*}{2} & Gender & Male & 22 & $12,4 \%$ \\
\hline & & Female & 156 & $87,6 \%$ \\
\hline & Total & & 178 & $100 \%$ \\
\hline \multirow[t]{10}{*}{3} & Education & $\mathrm{SD}$ & 1 & $0,6 \%$ \\
\hline & & SMP & 6 & $3,4 \%$ \\
\hline & & SMA & 37 & $20,8 \%$ \\
\hline & & SMK & 12 & $6,7 \%$ \\
\hline & & D2 & 1 & $0,6 \%$ \\
\hline & & D3 & 81 & $45,5 \%$ \\
\hline & & D4 & 2 & $1,1 \%$ \\
\hline & & $\mathrm{S} 1$ & 37 & $20,8 \%$ \\
\hline & & $\mathrm{S} 2$ & 1 & $0,6 \%$ \\
\hline & Total & & 178 & $100 \%$ \\
\hline \multirow[t]{7}{*}{4} & Long Work & $<1$ years & 14 & $7,9 \%$ \\
\hline & & $1-5$ years & 87 & $48,9 \%$ \\
\hline & & $6-10$ years & 52 & $29,2 \%$ \\
\hline & & $11-15$ years & 17 & $9,6 \%$ \\
\hline & & $16-20$ years & 4 & $2,2 \%$ \\
\hline & & $>20$ years & 4 & $2,2 \%$ \\
\hline & Total & & 178 & $100 \%$ \\
\hline
\end{tabular}


Table 1 shows that most employees at Aisyiyah Fatimah Hospital Tulangan Sidoarjo are aged between 21 - 30 years, namely 109 people $(61.2 \%)$. Based on gender, most of the respondents are women, namely 156 people $(87.6 \%)$. Based on education, and most respondents have D3 education as many as 81 people $(45.5 \%)$. Meanwhile, based on the length of work, most respondents worked for $1-5$ years as many as 87 people (48.9\%).

Table. 2

Characteristics of Respondents Based on Work Units

\begin{tabular}{|c|c|c|}
\hline The Work Unit & Frequency & Percentage (\%) \\
\hline Laboratory & 9 & $5,1 \%$ \\
\hline Emergency Room & 22 & $12,4 \%$ \\
\hline Medical Records & 12 & $6,7 \%$ \\
\hline Management & 8 & $4,5 \%$ \\
\hline Finance & 7 & $3,9 \%$ \\
\hline Radiology & 5 & $2,8 \%$ \\
\hline Pharmacy & 15 & $8,4 \%$ \\
\hline $\mathrm{HCA}$ & 8 & $4,5 \%$ \\
\hline Laundry & 4 & $2,2 \%$ \\
\hline IPS & 4 & $2,2 \%$ \\
\hline IT & 3 & $1,7 \%$ \\
\hline Nutrition & 7 & $3,9 \%$ \\
\hline Admin \& General & 3 & $1,7 \%$ \\
\hline Security & 4 & $2,2 \%$ \\
\hline Baby Room Installation & 9 & $5,1 \%$ \\
\hline Special Isolation Room & 11 & $6,2 \%$ \\
\hline Inpatient Installation 1 & 12 & $6,7 \%$ \\
\hline Central Surgical Installation & 6 & $3,4 \%$ \\
\hline Delivery Room Installation & 13 & $7,3 \%$ \\
\hline Driver & 5 & $2,8 \%$ \\
\hline Dental Clinic & 3 & $1,7 \%$ \\
\hline Cashier & 7 & $3,9 \%$ \\
\hline Outpatient Installation & 1 & $0,6 \%$ \\
\hline Total & 178 & $100 \%$ \\
\hline
\end{tabular}

The data above (Table 2) shows that based on work units, most of the respondents are in the IGD work unit as many as 22 people (12.4\%).

Table. 3

Characteristics of Respondents Based on COVID-19

Status According to the Profession

\begin{tabular}{lllll}
\hline No & Covid-19 Status & Profession & Frequency & Percentage \\
\hline 1 & Exposed to Covid-19 & Medical & 2 & \\
& & Nursing & 40 & \\
& & Other Names & 11 & \\
& & Non-Naked & 21 & $41,7 \%$ \\
\hline \multirow{2}{*}{2} & Not to Covid-19 & Total & 74 & $58,3 \%$ \\
& & Medical \& non- & 104 & \\
\hline & & medical & 178 & $100 \%$ \\
\hline
\end{tabular}


Table 3 above shows that based on the status of being exposed to Covid-19, most of the respondents had never been exposed to Covid-19, namely 104 people (58.3\%). In comparison, 74 people $(41.7 \%)$ were exposed to Covid-19, with the highest number in the nursing profession, as many as 40 people.

\section{Univariate Analysis}

Table. 4

Variable Categorization X1, X2, X3, X4

\begin{tabular}{clllcc}
\hline No & Variable & Category & Category & Frequency & Percentage \\
\hline 1 & Space $(X 1)$ & Low & $\mathrm{X}<7,28$ & 34 & $19,1 \%$ \\
& & Medium & $7,28 \leq \mathrm{X}<10,58$ & 144 & $80,9 \%$ \\
& & High & $10,58 \leq \mathrm{X}$ & 0 & $0,0 \%$ \\
\hline & & Total & 178 & $100 \%$ \\
\hline 2 & Staff $(X 2)$ & Low & $\mathrm{X}<18,32$ & 27 & $15,2 \%$ \\
& & Medium & $18,32 \leq \mathrm{X}<20,02$ & 37 & $20,8 \%$ \\
& & High & $20,02 \leq \mathrm{X}$ & 114 & $64,0 \%$ \\
\hline & & Total & 178 & $100 \%$ \\
\hline 3 & Stuff $(X 3)$ & Low & $\mathrm{X}<21,42$ & 32 & $18,0 \%$ \\
& & Medium & $21,42 \leq \mathrm{X}<28,74$ & 146 & $82,0 \%$ \\
& & High & $28,74 \leq \mathrm{X}$ & 0 & $0,0 \%$ \\
\hline & & Total & 178 & $100 \%$ \\
\hline 4 & System $(X 4)$ & Low & $\mathrm{X}<69,86$ & 29 & $16,3 \%$ \\
& & Medium & $69,86 \leq \mathrm{X}<83,34$ & 149 & $83,7 \%$ \\
& & High & $83,34 \leq \mathrm{X}$ & 0 & $0,0 \%$ \\
\hline & & Total & 178 & $100 \%$ \\
\hline
\end{tabular}

Based on table 4 the results of the descriptive analysis on the Space (X1) variable were obtained by respondents who assessed Space (X1) in the medium category as many as 144 people $(80.9 \%)$. At the same time, the results of the descriptive analysis on the Staff variable (X2) obtained respondents who assessed the Staff (X2) in the high category as many as 114 people (64.0\%). In the results of descriptive analysis on the Stuff variable (X3), it was found that 146 respondents $(82.0 \%)$. Furthermore, the results of the descriptive analysis on the System variable (X4) obtained respondents who assessed the System variable (X4) in the medium category, namely as many as 149 people $(83.7 \%)$.

\section{T-Test}

Table. 5

Hypothesis Testing Results (t-Test)

\begin{tabular}{|c|c|c|c|c|c|c|c|c|c|}
\hline \multirow[t]{2}{*}{ No } & \multirow[t]{2}{*}{ Variable } & \multirow[t]{2}{*}{ B } & \multicolumn{3}{|c|}{ Influence } & \multicolumn{3}{|c|}{$\begin{array}{c}\text { Significant } \\
\alpha=0,05\end{array}$} & \multirow[t]{2}{*}{ Information } \\
\hline & & & count & $\langle/\rangle$ & count & Sig. & $\langle/\rangle$ & $\alpha$ & \\
\hline 1 & $\begin{array}{l}\text { Space } \rightarrow \text { Suspect } \\
\text { COVID-19 }\end{array}$ & $-0,217$ & $-2,033$ & $<$ & $-2,017$ & 0,048 & $<$ & 0,05 & $\begin{array}{c}\text { H1 } \\
\text { accepted }\end{array}$ \\
\hline 2 & $\begin{array}{l}\text { Staff } \rightarrow \text { Suspect } \\
\text { COVID-19 }\end{array}$ & 0,277 & 3,015 & $>$ & 2,017 & 0,004 & $<$ & 0,05 & $\begin{array}{c}\mathrm{H} 2 \\
\text { accepted }\end{array}$ \\
\hline 3 & $\begin{array}{l}\text { Stuff } \rightarrow \text { Suspect } \\
\text { COVID-19 }\end{array}$ & $-0,123$ & $-2,192$ & $<$ & $-2,017$ & 0,034 & $<$ & 0,05 & $\begin{array}{c}\mathrm{H} 3 \\
\text { accepted }\end{array}$ \\
\hline 4 & $\begin{array}{l}\text { System } \rightarrow \text { Suspect } \\
\text { COVID-19 }\end{array}$ & $-0,056$ & $-2,156$ & $<$ & $-2,017$ & 0,037 & $<$ & 0,05 & $\begin{array}{c}\mathrm{H} 4 \\
\text { accepted }\end{array}$ \\
\hline
\end{tabular}




\begin{tabular}{|c|c|c|c|c|c|c|c|c|c|}
\hline 5 & $\begin{array}{l}\text { Space } \rightarrow \text { Confirm } \\
\text { COVID-19 }\end{array}$ & $-0,487$ & $-2,094$ & $<$ & $-2,017$ & 0,042 & $<$ & 0,05 & $\begin{array}{c}\text { H5 } \\
\text { accepted }\end{array}$ \\
\hline 6 & $\begin{array}{l}\text { Staff } \rightarrow \text { Confirm } \\
\text { COVID-19 }\end{array}$ & $-0,413$ & $-2,066$ & $<$ & $-2,017$ & 0,045 & $<$ & 0,05 & $\begin{array}{c}\mathrm{H6} \\
\text { accepted }\end{array}$ \\
\hline 7 & $\begin{array}{l}\text { Stuff } \rightarrow \text { Confirm } \\
\text { COVID-19 }\end{array}$ & $-0,260$ & $-2,135$ & $<$ & $-2,017$ & 0,039 & $<$ & 0,05 & $\begin{array}{c}\mathrm{H} 7 \\
\text { accepted }\end{array}$ \\
\hline 8 & $\begin{array}{l}\text { System } \rightarrow \\
\text { Confirm COVID } \\
19\end{array}$ & $-0,184$ & $-3,250$ & $<$ & $-2,017$ & 0,002 & $<$ & 0,05 & $\begin{array}{c}\mathrm{H} 8 \\
\text { accepted }\end{array}$ \\
\hline
\end{tabular}

Based on Table 7, the effect of Space (X1) on the Number of Suspected Covid-19 Patients (Y1) is -0.217 and has a negative value, has a value of $\mathrm{t}$-count $=-2,033<\mathrm{t}$-table $(-$ $2,017)$ with a sig value. $0.048<0.05$, then $\mathrm{H} 0$ is rejected and $\mathrm{H} 1$ is accepted. The influence of staff (X2) on the number of suspected Covid-19 patients (Y1) is 0.277 and has a positive value, having a value of $t$-count $=3.015>t$-table (2.017) with a sig value. $0.004<0.05$, then $\mathrm{H} 0$ is rejected and $\mathrm{H} 2$ is accepted. The effect of Stuff (X3) on the Number of Suspected Covid-19 Patients (Y1) is -0.123 and is negative, has a value of $\mathrm{t}$-count $=-2.192$ $<\mathrm{t}$-table (-2.017) with a sig value. $0.034<0.05$, then $\mathrm{H} 0$ is rejected and $\mathrm{H} 3$ is accepted. The effect of the System (X4) on the Number of Suspected Covid-19 Patients (Y1) is -0.056 and has a negative value, has a value of $\mathrm{t}$-count $=-2.156<\mathrm{t}$-table $(-2.017)$ with a value of sig. $0.037<0.05$, then $\mathrm{H} 0$ is rejected and $\mathrm{H} 4$ is accepted.

The effect of Space (X1) on the Number of Confirmed Covid-19 Patients (Y2) is 0.487 and has a negative value, has a value of $t$-count $=-2,094<\mathrm{t}$-table $(-2,017)$ with a sig value. $0.042<0.05$, then $\mathrm{H} 0$ is rejected and $\mathrm{H} 5$ is accepted. The influence of Staff (X2) on the Number of Confirmed Covid-19 Patients (Y2) is -0.413 and is negative, has a value of tcount $=-2,066<\mathrm{t}$-table $(-2,017)$ with a sig value. $0.045<0.05$, then $\mathrm{H} 0$ is rejected and $\mathrm{H} 6$ is accepted. The effect of Stuff (X3) on the Number of Confirmed Covid-19 Patients (Y2) is -0.260 and has a negative value, has a value of $t$-count $=-2.135<\mathrm{t}$-table $(-2.017)$ with a sig value. $0.039<0.05$, then $\mathrm{H} 0$ is rejected and $\mathrm{H} 7$ is accepted.

\section{DISCUSSION}

\section{The effect of space on the number of suspected Covid-19 patients}

The results showed that the distribution of respondents who assessed Space (X1) was in the medium category as many as 144 people (80.9\%). From the regression coefficient (b1), the Space variable (X1) was -(0.217) had a negative and significant effect on the dependent variable is the number of suspected Covid-19 patients (Y1). If the Space variable (X1) increases, the variable number of Suspected Covid-19 Patients (Y1) will decrease. With the readiness of variable space in hospitals, unique protocols in managing isolation rooms and monitoring the movement of patients with suspected Covid-19 will be more controlled with lower occupancy (Carenzo et al., 2020).

The result of the influence of Space (X1) on the Number of Suspected COVID-19 Patients (Y1) is - (0.217) and is negative, has a value of t-count $=-2,033<\mathrm{t}$-table $(-2,017)$ with a sig value. $0.048<0.05$, then $\mathrm{H} 0$ is rejected, and $\mathrm{H} 1$ is accepted. This shows that hypothesis 1 (H1) states an effect of facility readiness (space) in handling Covid-19 on the number of suspected Covid-19 patients at Aisyiyah Siti Fatimah Hospital, Tulangan Sidoarjo, was accepted. Hospital readiness in dealing with the Covid-19 pandemic by accommodating requests for additional patient bed capacity, extraordinary ICU beds, or critical patient care areas with ventilator equipment and oxygen supply will affect the management of patients with suspected Covid-19 (Barasa et al., 2020). 
This is also in line with Carenzo et al., (2020) research that the faster the spread of disease, it is essential for hospitals to anticipate a spike in cases by increasing capacity, especially the cohort system beds and unfavorable ventilation system isolation rooms. In addition, the design of appropriate screening procedures through pre-triage of suspected Covid-19 cases to monitor patient movements also affects the planning of isolation beds in hospitals. Therefore, the higher the space ready for suspected Covid-19 patients, the lower the incidence rate. Because the number of cases can be managed and controlled correctly and does not exceed the existing capacity in the hospital.

\section{The Influence of Staff on the Number of Suspected Covid-19 Patients}

The results showed that the distribution of respondents who assessed Staff (X2) was in the high category as many as 114 people $(64.0 \%)$, and the results of the regression coefficient (b2) Staff variable (X2) was 0.277 , had a positive and significant effect on the dependent variable. The number of Suspected Covid-19 Patients (Y1). The number of suspected Covid-19 cases can follow the increase in staff variables. Based on the research results by Suleiman et al., (2020) there is a significant relationship between the readiness of Staff who handle suspected Covid-19 patients, both quantitatively and psychologically, especially doctors as the frontline. It is increasing, especially for frontline doctors, suspected Covid-19 patients will be found more quickly because tracing with close contacts is maximized.

From the calculation results, it is found that the influence of Staff (X2) on the Number of Suspected Covid-19 Patients (Y1) is 0.277 and has a positive value, having a value of t-count $=3.015>\mathrm{t}$-table (2.017) with a sig value. $0.004<0.05$, then $\mathrm{H} 0$ is rejected, and $\mathrm{H} 2$ is accepted. This shows that hypothesis $2(\mathrm{H} 2)$ states an effect of preparedness of human resources (Staff) in handling Covid-19 on the number of suspected Covid-19 patients at Aisyiyah Siti Fatimah Hospital, Tulangan Sidoarjo, was accepted. Human resources (Staff) are critical success factors in optimizing services for Covid-19 patients (Carenzo et al., 2020).

In addition to physical readiness, the mentality of all Staff must also be considered. A study revealed that health workers working in Wuhan often feel stress, depression, and anxiety. Frontline nurses experience various mental health challenges, especially fatigue and fear, thus requiring attention and support from policymakers to improve mental health, build strength and resilience, provide efficient social support provisions, and ensure willingness to work in hospitals with Covid-19 (Hu et al., 2020).

\section{The Effect of Stuff on the Number of Suspected Covid-19 Patients}

The results showed that the distribution of respondents who assessed the Stuff variable $(\mathrm{X} 3)$ in the medium category was 146 people $(82.0 \%)$. The regression coefficient (b3) of the Stuff variable (X3) was -0.123. A negative and significant effect on the dependent variable is the number of patients with suspected Covid-19 (Y1). The result of the effect of Stuff (X3) on the Number of Suspected Covid-19 Patients (Y1) is -0.123 and is negative, has a value of $\mathrm{t}$-count $=-2.192<\mathrm{t}$-table $(-2.017)$ with a sig value. $0.034<0.05$, then $\mathrm{H} 0$ is rejected, and $\mathrm{H} 3$ is accepted. This shows that hypothesis 3 (H3) states an effect of equipment readiness and drugs (Stuff) in handling Covid-19 on the number of suspected Covid-19 patients at Aisyiyah Siti Fatimah Hospital, Sidoarjo, was accepted.

Based on the study results by Maulana \& Mynawati (2021) the readiness and availability of hospital staff significantly affect the security and confidence of officers in handling Covid-19 patients, especially in patients with suspected Covid-19 triage results. 
This is by the readiness at Aisyiyah Siti Fatimah Hospital, Tulangan Sidoarjo. The hospital has provided infection prevention, control protocols, and adequate personal protective equipment (medical and surgical masks, N95 respirators, gloves, gowns, and eye protection) available and easy to use. Accessible to all hospital staff, the hospital has also prepared infrastructure, infection prevention, and control training to carry out management according to procedures for suspected Covid-19 patients.

\section{The Influence of the System on the Number of Suspected Covid-19 Patients}

From the results of the study, it was found that the System (X4) was included in the medium category as many as 149 people $(83.7 \%)$, where the hospital had provided a lead management system, coordination and communication, information management, and supervision, risk communication and community involvement, administration, finance and business continuity, patient management and has made guidelines for the identification and rapid diagnosis of Covid-19 patients.

In the results of the regression coefficient (b4), the System variable (X4) is -0.056 , has a negative and significant effect on the dependent variable, the Number of Patients with Suspected Covid-19 (Y1), if the System variable (X4) increases, then the variable Number of Suspected Covid-19 (Y1) ) will decrease. The readiness of the system to handle incidents of Covid-19 patients has a vital role in the successful handling of Covid-19 patients, especially coordination and communication (Carenzo et al., 2020).

Meanwhile, the effect of System (X4) on the Number of Suspected COVID-19 Patients (Y1) is -0.056 and has a negative value, has a value of $\mathrm{t}$-count $=-2.156<\mathrm{t}$-table $(-$ 2.017 ) with a value of sig. $0.037<0.05$, then $\mathrm{H} 0$ is rejected, and $\mathrm{H} 4$ is accepted. This shows that hypothesis $4(\mathrm{H} 4)$ states an effect of preparedness of management policies and processes (systems) in handling Covid-19 on the number of suspected Covid-19 patients at Aisyiyah Siti Fatimah Hospital, Sidoarjo, was accepted. This can be proven by hospital policies that have formed a Covid-19 disaster team; hospitals have also implemented guidelines related to Covid-19 risk management. Moreover, no less important is the hospital having a triage protocol for patients with suspected Covid-19 procedures for receiving and transferring patients to areas within the hospital.

In Singapore, the anesthesiology division prepared the system by developing measures to facilitate the care of patients with known or suspected Covid-19 requiring surgery and to reduce the risk of virus transmission, including operating room settings, modification of workflows and processes, Staff and patient management. And the formulation of clinical guidelines for anesthetic management (Wong et al., 2020).

\section{The Effect of Space on the Number of Confirmed Covid-19 Patients}

In the Space variable on the number of confirmed Covid-19 patients, the results of the regression coefficient (b1) for the Space variable (X1) are -0.487 , a negative and significant effect on the dependent variable on the number of confirmed Covid-19 patients (Y2), if the Space variable (X1) increases. The variable Number of Confirmed Covid-19 Patients (Y2) will decrease. This is by the research of Cao et al., (2020) on the Covid-19 disaster emergency management plan in Chinese hospitals; hospitals invest in treatment rooms to build an emergency management system based on anticipated hazards.

Meanwhile, the result of the effect of Space (X1) on the number of confirmed COVID-19 patients (Y2) is -0.487 and is negative, has a value of count $=-2,094<$ table $(-$ 2,017 ) with a sig value. $0.042<0.05$, then $\mathrm{H} 0$ is rejected, and H5 is accepted. This shows that hypothesis 5 (H5) states that facility readiness (space) in handling Covid-19 on the 
number of confirmed Covid-19 patients at Aisyiyah Siti Fatimah Hospital Tulangan Sidoarjo is accepted. This is evidenced by the conditions at Aisyiyah Siti Fatimah Hospital, Tulangan Sidoarjo. The hospital has improved critical area competence, increased the number of isolation room beds, and created systems and mechanisms to handle spikes in cases.

The Covid-19 pandemic is causing unprecedented pressure; in New York, several attempts are being made to increase space requirements, from the cancellation of elective surgeries to the push to double the beds in medical wards and intensive care wards for the handling of Covid-19 cases (Klein et al., 2020).

\section{The Influence of Staff on the Number of Confirmed Covid-19 Patients}

In the staff variable on the number of confirmed COVID-19 patients, the regression coefficient (b2) of the Staff variable (X2) is -0.413 , a negative and significant effect on the dependent variable on the number of confirmed Covid-19 patients (Y2), if the Staff variable (X1) increases. The variable Number of Confirmed Covid-19 Patients (Y2) will decrease. This is following the research of Carenzo et al. (2020); the higher the readiness of the Staff in the hospital, the more optimal handling of confirmed COVID-19 patients so that the number of patients will decrease.

The results of the influence of Staff (X2) on the number of Confirmed Covid-19 Patients (Y2) is -0.413 and is negative, has a value of count $=-2,066<$ table $(-2,017)$ with a sig value. $0.045<0.05$, then $\mathrm{H} 0$ is rejected, and $\mathrm{H} 6$ is accepted. The results show that hypothesis 6 (H6) influences the readiness of human resources (Staff) in handling Covid-19 on the number of confirmed Covid-19 patients at Aisyiyah Siti Fatimah Hospital, Tulangan Sidoarjo, is accepted. This is by the condition of the hospital, which has estimated the capacity of its human resources to prepare and respond to the potential spike in need for Covid-19 cases, improve the competence and safety of Staff; the Staff is always given training and education following their duties and responsibilities, especially material on PPI and governance. Clinical management and procedures for setting up and assigning hospital staff as a strategy for service continuity.

The training of doctors, nurses, and health assistants is carried out with live demonstrations and in-situ simulations. Not only are Staff working on Covid-19 patients required to attend training, but it is also required for staff members. The 60 -minute training program is designed and delivered by critical care consultants and infection control nurses with specialist support. It is designed so that it can be attended by all health workers and does not interfere with their shifts (Batubara et al., 2021).

\section{The Effect of Stuff on the Number of Confirmed Covid-19 Patients}

In the regression coefficient (b3), the Stuff variable (X3) is -0.260 has a negative and significant effect on the dependent variable Number of Confirmed COVID-19 Patients (Y2) if the Stuff variable (X3) increases. The variable number of confirmed COVID-19 patients (Y2 ) will decrease. Similar to patients with suspected COVID-19, the readiness of Staff in handling COVID-19 will increase. The management of patients with confirmed COVID-19 can be carried out optimally so that the incidence of confirmed COVID-19 patients will be increased will decrease.

For the calculation results of the effect of Stuff (X3) on the number of confirmed Covid-19 patients (Y2), it is -0.260 and has a negative value, has a count $=-2.135<$ table $(-$ 2.017 ) with a sig value. $0.039<0.05$, then $\mathrm{H} 0$ is rejected, and $\mathrm{H} 7$ is accepted. This shows that hypothesis 7 (H7) states an effect of equipment and drug readiness (Stuff) in handling 
Covid-19 on the number of confirmed Covid-19 patients at Aisyiyah Siti Fatimah Hospital Tulangan Sidoarjo.

According to Krisnawati et al., (2020) hospitals must have prepared Stuff, including identifying backup resources, supporting services such as oxygen stocks, cleaning materials, disinfectants, and infection prevention and control (PPI) facilities and infrastructure. Putra (2018) added that the readiness of hospitals to provide personal protective equipment (PPE) for operations for confirmed Covid-19 patients would affect comfort and performance in handling Covid-19 cases.

\section{The Influence of the System on the Number of Confirmed Covid-19 Patients}

The results of the regression coefficient (b4) for the System variable (X4) of -0.184, a negative and significant effect on the dependent variable the Number of Confirmed Covid19 Patients (Y2), if the System variable (X4) increases, then the variable Number of Confirmed Covid-19 Patients (Y2) ) will decrease. This is the same as the variable for Covid-19 suspects, where the readiness of the system to handle incidents of Covid-19 patients has a vital role in the successful handling of Covid-19 patients, especially coordination and communication (Carenzo et al., 2020).

Meanwhile, the result of calculating the effect of System (X4) on the Number of Confirmed Covid-19 Patients (Y2) is -0.184 and has a negative value, having a value of count $=-3.250<$ table $(-2.017)$ with a sig value. $0.002<0.05$, then $\mathrm{H} 0$ is rejected, and $\mathrm{H} 8$ is accepted. This shows that hypothesis 8 (H8) states an effect of preparedness of management policies and processes (systems) in handling Covid-19 on the number of confirmed Covid19 patients at Aisyiyah Siti Fatimah Hospital, Sidoarjo, was accepted.

In health care in Europe, the system's readiness in handling Covid-19 will be better able to cope with pressure than those that do not have the readiness of the system Batubara et al., (2021). Gao \& Chen (2020) added that hospitals should prepare for surgical patient management with a high standard of care during the Covid-19 pandemic. Hospitals should evaluate whether there are considerations for delaying elective patients, and surgeons should oversee the safety measures in the room. Operation. Trained Staff, adequate instruments, and strict recommendations are essential to avoid an increased risk of contamination in case of a lack of skills or adapted materials that allow safe laparoscopic surgical intervention.

\section{CONCLUSION}

Space, Staff, and System have a negative and significant effect on the number of suspected Covid-19 patients. If the Space, Stuff, and System increase, the variable Number of Suspected Covid-19 Patients will decrease. The Staff has a positive and significant effect on the number of patients with suspected Covid-19; if the Staff increases, then the variable number of patients with suspected Covid-19 will also increase.

Space, Stuff, and System have a negative and significant effect on the number of Confirm Covid-19 patients. If the Space, Stuff, and System increase, the variable Number of Confirm Covid-19 Patients will decrease. Space, Stuff, and System simultaneously significantly affect the Number of Suspected and Confirmed Covid-19 Patients.

\section{SUGGESTIONS}

\section{For further researchers}

Researching the effect of hospital readiness on optimizing services for Covid-19 patients with quality indicators set by the Ministry of Health. Research on supporting 
factors and inhibiting factors that affect hospital readiness in handling Covid-19. They are conducting hospital readiness research with mixed-method research so that the results obtained are more comprehensive.

\section{For the hospital}

Analyze staff needs, Staff to achieve optimization of the handling of Covid-19. It is evaluating space and systems on an ongoing basis by adjusting the regulations guidelines that the Government has set.

\section{REFERENCES}

Abbasabadi, A. M., Khankeh, H. R., Mosadeghrad, A. M., \& Farrokhi, M. (2019). Developing a Hospital Disaster Risk Management Evaluation Model. Risk Management and Healthcare Policy, 12, 287-296. DOI: 10.2147/RMHP.S215444

Barasa, E. W., Ouma, P. O., \& Okiro, E. A. (2020). We are Assessing the Hospital Surge Capacity of the Kenyan Health System in the Face of the Covid-19 Pandemic. Plus One, 15(7). DOI: 10.1371/journal.pone.0236308

Batubara, S., Akbar, S., \& Batubara, I. A. (2021). Kesiapan Pembelajaran Klinik di Masa Pandemi Covid-19. Biology Education Science \& Tecnology Journal, 4(1), 39-45. https://jurnal.uisu.ac.id/index.php/best/article/view/3653

Carenzo, L., Costantini, E., Greco, M., Barra, F. L., Rendiniello, V., Mainetti, M., Bui, R., Zanella, A., Grasselli, G., Lagioia, M., Protti, A., \& Cecconi, M. (2020). Hospital Surge Capacity in a Tertiary Emergency Referral Centre During the Covid-19 Outbreak in Italy. Anaesthesia, 75(7), 928-934. DOI: 10.1111/anae.15072

Cao, Y., Li, Q., Chen, J., Guo, X., Miao, C., Yang, H., Chen, Z., Li, C., \& Li, L. (2020). Hospital Emergency Management Plan During the Covid-19 Epidemic. Academic Emergency Medicine, 27(4), 309-311. DOI: 10.1111/acem.13951

Gao, Y., Xi, H., \& Chen, L. (2020). Emergency Surgery in Suspected Covid-19 Patients With Acute Abdomen: Case Series and Perspectives. Annals of Surgery, 272, (1), e38-e39. DOI: 10.1097/SLA.0000000000003961

Gupta, S., \& Federman, D. G. (2020). Hospital Preparedness for Covid-19 pandemic: Experience from the medicine department at Veterans Affairs Connecticut Healthcare System. Postgraduate Medicine, 132(6), 489-494. DOI: 10.1080/00325481.2020.1761668

Hu, D., Kong, Y., Li, W., Han, Q., Zhang, X., Zhu, L. X., Wen, S. W., Liu, Z., Shen, Q., Yang, J., He, H.-G., \& Zhu, J. (2020). Frontline Nurses' Burnout, Anxiety, Depression, and Fear Statuses and Their Associated Factors During the Covid-19 Outbreak in Wuhan, China: A Large-Scale Cross-Sectional Study. E-Clinical Medicine, 24, 100424. DOI: 10.1016/j.eclinm.2020.100424

Kaito, D., Matsumura, K., \& Yamamoto, R. (2020). Hospital Preparedness for COVID-19: The Known and The Known Unknown. The Keio Journal of Medicine, 70(2), 25-34. DOI: 10.2302/kjm.2020-0011-OA

Klein, M. G., Cheng, C. J., Lii, E., Mao, K., Mesbahi, H., Zhu, T., Muckstadt, J. A., \& Hupert, N. (2020). Covid-19 Models for Hospital Surge Capacity Planning: A Systematic Review. Disaster Medicine and Public Health Preparedness, 1-8. DOI: 10.1017/dmp.2020.332

Krisnawati, M., Pitaloka, J., \& Adriansyah, J. (2020). Resiko dan Upaya Pencegahan Pandemi Covid-19 Bagi Masyarakat RSPAU dr. S. Hardjolukito. Jurnal Abdimas Madani, 2(2), 45-50. https://abdimasmadani.ac.id/index.php/abdimas/article/view/33 
Maulana, M. S. A \& Mynarwati, M. (2021). Rumah Sakit Siaga Covid-19. Excellent Journal, $4(2)$, 84-90. https://jurnal.mitrahusada.ac.id/index.php/emj/article/view/159

Padila, P., Rinaldi, S., Andri, J., Harsismanto, J., \& Andrianto, M. B. (2021). Stres dengan Sistem Pembelajaran Online pada Mahasiswa di Era Pandemi COVID-19. Journal of Telenursing (JOTING), 3(2), 591-599. https://doi.org/10.31539/joting.v3i2.2699

Pole, J, S., Andri, J., \& Padila, P. (2021). Cardiovascular Patient's Anxiety in the Time of the Covid-19 Pandemic. JOSING: Journal of Nursing and Health, 2(1), 15-21. https://doi.org/10.31539/josing.v2i1.3022

Putra, H. A. (2018). Studi Kualitatif Kesiapsiagaan Tim Komite Bencana Rumah Sakit PKU Muhammadiyah Bantul dalam Menghadapi Bencana. Health Sciences and Pharmacy Journal, 2(1), 8. DOI: 10.32504/hspj.v2i1.22

Suleiman, A., Bsisu, I., Guzu, H., Santarisi, A., Alsatari, M., Abbad, A., Jaber, A., Harb, T., Abuhejleh, A., Nadi, N., Aloweidi, A., \& Almustafa, M. (2020). Preparedness of Frontline Doctors in Jordan Healthcare Facilities to COVID-19 Outbreak. International Journal of Environmental Research and Public Health, 17(9), 3181. DOI: 10.3390/ijerph17093181

Utami, Y. P. D., Pinzon, R. T., \& Meliala, A. (2021). Evaluasi Kesiapan Rumah Sakit Menghadapi Bencana Non-Alam : Studi Kasus Covid-19 di Rumah Sakit Bethesda Yogyakarta. Jurnal Kebijakan Kesehatan Indonesia, 10(2), 100-106. https://doi.org/10.22146/jkki.61686

WHO. (2021). WHO Coronavirus (COVID-19) Dashboard. from https://covid19.who.int

Wong, S. H., Lui R. N. S., \& Sung, J. Y. S. (2020). Covid-19 and the Digestive System. Journal of Gastroenterology and Hepatology, 35(5), 744-748. https://doi.org/10.1111/jgh.15047

Yuliana, Y. (2020). Corona Virus Diseases (Covid-19): Sebuah Tinjauan Literatur. Wellness and Healthy Magazine, 2(1), 187-192. https://wellness.journalpress.id/wellness/article/view/21026/pdf 